\title{
Effect of green colour on glass quality
}

\author{
Shatha S. M. Al-azzawi \\ Department of Physics., College of science, University of Baghdad \\ E-mail: shatha_alazzawi@yahoo.com
}

\begin{abstract}
The study of green colour in glass has a special importance on the glass quality, specially the effect of ferrous oxides content of the limestone. Results obtained that there was a reduction in green colour when different ferrous oxide contents in the limestone were added in glass production, limestone sources from two quarries, and the first contains $0.67 \%$ ferrous oxide and the second posses less ferrous oxide.

Reduction of green colour showed higher transmittance12\% and it could be suggested that reduction of ferrous oxides content in the limestone is of special importance on the optical properties of glass.
\end{abstract}

Key words

Green colour, glass quality, glass production, Optical properties.

\section{Article info}

Received: Dec. 2012

Accepted: Mar. 2013

Published: Apr. 2013

$$
\begin{aligned}
& \text { تأثير اللون الاخضر على نوعية الزجاج } \\
& \text { شذى صالح العزاوي } \\
& \text { قسم الفيزياء، كلية العلوم، جامعة بغداد }
\end{aligned}
$$

\section{Introduction}

The study of raw material of glass industry has become of great importance for glass quality as well as the economic importance of providing local sources of raw material for this industry.

Although, national studies and reports available[1,2] had shown that raw material from certain districts local causes defects in glass manufactured, specially the presence of green colour as a result of the presence of ferric oxides in limestone used in glass manufacturing.

Studies available on the effect of ferric oxides on the presence of green colour in glass $[3,4]$ had shown that increase of ferric oxide content in raw material had increased the presence of green colour, meanwhile this causes decreased in demand for the glass as well as direct effect on the physical properties of glass[5-7]. 
Therefore this research aims to study the effect of green colour on the transmitivity of glass, and study the possibilities of reducing green colour in glass produced, as well as the necessity of finding new quarries for limestone with lower ferrous oxide contents.

\section{Treatment of Green Colour in Glass}

Green colour in glass could be reduced by several methods [8], and it could be concluded as follow:

- Physical Methods: This method depend on the addition of colouring materials to complement the green colour, the glass produced is colourless with low transparency [9-14]. The most important additive are selenium oxide, cobalt oxides.

The quantity of these additives depends on the amount of ferric oxides present in raw material used in glass manufacturing.

- Chemical Method: In this method, ferrous oxides converted to ferric oxide by oxidation. Ferric oxides cause less intensity of green colour than ferrous oxides [8-11, 13 and 14]. Glass produced will be of lower green colour intensity, with minimum effect on glass transparency.

The most important agents used in this process are:

$\mathrm{NaNO}_{3}$ or $\mathrm{KNO}_{3}+\mathrm{As}_{2} \mathrm{O}_{3}$

$\mathrm{NaNO}_{3}$ or $\mathrm{KNO}_{3}+\mathrm{Ab}_{2} \mathrm{O}_{3}$

$\mathrm{NaNO}_{3}$ or $\mathrm{KNO}_{3}+\mathrm{Na}_{2} \mathrm{SO}_{3}$

$\mathrm{MnO}_{2} \quad$ (Manganese oxide)

$\mathrm{CeO}_{2} \quad$ (Cerium oxide)

$\mathrm{Nd}_{2} \mathrm{O}_{3} \quad$ (Neodymium oxide)

- Physicochemical Method: These methods depends on the addition of colouring agents which compliment the green colour such as oxides of selenium and cobalt, as well as the oxidation of ferrous oxide to ferric oxide by using oxidative agents such as sodium nitrate[8,9,11,13and14].

\section{Transmittance of colourless glass}

Light transmitivity through glass, is the percentage of the intensity of light transmitted to the intensity of light incident on glass surface. Part of light intensity will be lost as a result of absorption or reflection of light $[13,15]$.

Glass appears colourless when transmitivity increased at wave length(400-700) $\mathrm{nm}$. This could be due to:

- The stature of the glass, as is the case with other materials, results in the appearance of distinct absorption bands, which is consequence of electronic transition from its initial state and is called the fundamental absorption band.

- Presence of coloured impurities in the glass such as ferric oxide which causes effect on transmitivity.

Therefore it could be concluded that transmitivity effected either by the structure of glass or the presence of colouring impurities. Increasing of these impurities has an adverse on the quality of the glass and its physical and chemical properties.

\section{Experimental procedure}

There are three glass samples used in this research

Sample 1 (GIRIOO) Government Industrial Research Institute, Osaka/Japan Standard Glass

Sample 2 Glass prepared from limestone with lower ferric oxide content from the second quarry.

Sample 3 Glass prepared from limestone with higher ferric oxide content from the first quarry.

Transmittance of these samples were measured by spectrophotometer type LAMBDA-9 PERKIN-ELMER range 
(300 -800) nm.

The chemical analysis for the limestone was carried out in the laboratory of directorate general of the geological survey and minerals investigation.

\section{Results and Discussion}

Average measurement of transmitivity for the three glass samples by spectrophotometer at (360-740) $\mathrm{nm}$ were presented in Table 1.

Table1: Transmittance for three glass samples $(1,2$, and 3$)$

\begin{tabular}{|c|c|}
\hline Samples & $\begin{array}{c}\text { Average } \\
\text { Transmittance } \%\end{array}$ \\
\hline 1 & 91.93 \\
\hline 2 & 84.75 \\
\hline 3 & 72.87 \\
\hline
\end{tabular}

Fig.1 presents the relationship between transmittance against wavelength for the three glass samples, transmitivity were calculated at range of wavelength (400700)nm.

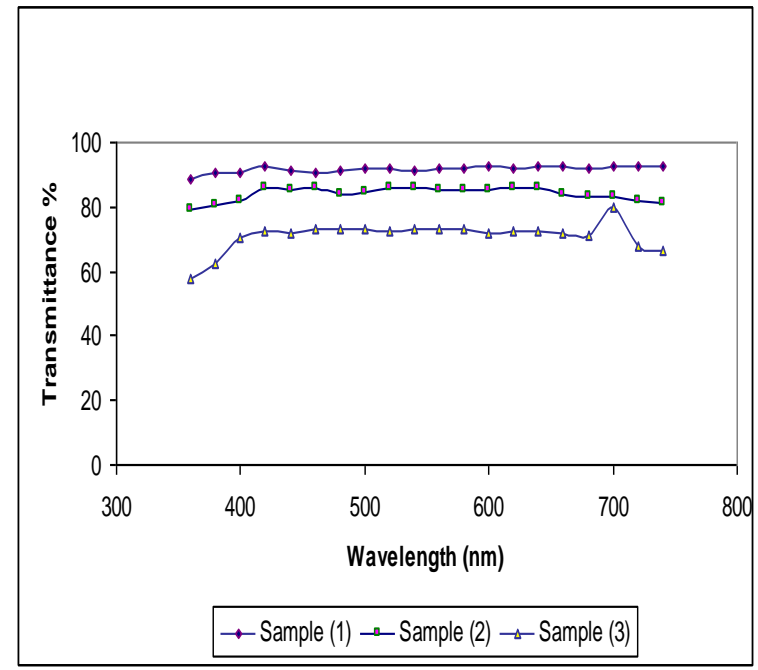

Fig.1: Variation of transmittance with the wavelength of the three different glass samples.

An increase of about $12 \%$ in transmittance has been observed for glass samples prepared from limestone with lower ferric oxide content of the second quarry than those of glass samples of limestone with higher ferric oxide content of the first quarry. This was due to the reduction of green colour in glass. we see that transmittance is approximately constant for sample 1 and 2 . for sample 3 note the presence of a jump at the wavelength (700nm ) and we think it is because of a defect in the manufacturing of glass

We can see a clear difference of the transmittance of the glass samples because of the different content material. The transmittance of sample (1) is more value than that for sample (2) and (3).

Lose of $8 \%, 4 \%$ for each surface transmittance lose was calculate as:

$\mathrm{R}=(\mathrm{n}-1 / \mathrm{n}+1)^{2}=0.04$

where

$\mathrm{R}=$ Reflection $=4 \%$ on each surface

$\mathrm{n}=$ Refractive index $=8 \%$ reflection on both surfaces

$\mathrm{n}=$ about 1.5 for most common crow glass

Chemical analysis of the three glass samples are shown in Table 2.

Table 2: Chemical analysis of the three different sample of glass

\begin{tabular}{|c|c|c|c|}
\hline Constituents & $\begin{array}{c}\text { Sample } \\
\mathbf{1}\end{array}$ & $\begin{array}{c}\text { Sample } \\
\mathbf{2}\end{array}$ & $\begin{array}{c}\text { Sample } \\
\mathbf{3}\end{array}$ \\
\hline$\% \mathrm{CaO}$ & 9.990 & 55.13 & 54.29 \\
\hline$\% \mathrm{Fe}_{2} \mathrm{O}_{3}$ & 0.008 & 0.04 & 0.15 \\
\hline$\% \mathrm{SiO}_{2}$ & 72.400 & 0.71 & 0.88 \\
\hline$\% \mathrm{Al}_{2} \mathrm{O}_{3}$ & 1.430 & 0.65 & 0.49 \\
\hline$\% \mathrm{MgO}$ & 1.890 & 0.28 & 0.37 \\
\hline$\% \mathrm{~L} . \mathrm{O} . \mathrm{I}$. & ------ & 43.20 & 43.26 \\
\hline$\% \mathrm{Na}_{2} \mathrm{O}$ & 3.040 & ------ & ----- \\
\hline$\% \mathrm{~K}_{2} \mathrm{O}$ & 0.500 & ----- & ----- \\
\hline$\% \mathrm{As}_{2} \mathrm{O}_{3}$ & 0.200 & ------ & ----- \\
\hline
\end{tabular}

\section{Conclusions}

We conclude from above data the following:

- Limestone from different place differ in ferric oxide content 
- The quality of glass affected by these differences specially the presence of green colour.

- It will be of great importance to find raw material for the glass industry with minimum content of ferric oxides. Though, it must be noted that ferric oxide content in limestone of the second quarry is equal $0.04 \%$ and for the third sample limestone of the first quarry is $0.15 \%$.

- Increasing ferric oxide content leads to diminish light transmission.

- Calcium oxide for sample two causes an increase of transmittance of glass from $72.87 \%$ to $84.75 \%$, the transmittance of standard glass is known to be $91.93 \%$.

- Decreasing ferric oxide content by use of mordant or colourings materials lead to an increase in the cost of production of the glass and loss in foreign in currency. Therefore it will be of special importance of finding local resources for limestone.

\section{References}

[1] N.Gueguen , Current Psychology Letters 2 (2003) 11.

[2] S.Al-Azzawi, F.Yasin, Solar and Wind Technology, 21 (1985) 41.

[3]S.Chaiyapinunt, N. Khamporn, Engineering Journal 131 (2009) 0125.

[4]F.K. Polokhlivet, I.A.Klyuchnik, V.I. Kiyan, Glass and Ceramics, 55, 2(1998) 9.
[5] S.Chaiyapinunt, B.Phueakphongsuriya, K.Mongkornsaksit, N. Khomporn, Energy and Buildings 37, 7 (2005) 725.

[6] Bamford C.R., "Colour Generation and Control in Glass", Elsevier Scientific pub.Co.U.S.and Canada 224 (1977).

[7] F. V. Tooley, "HandBook of Glass Manufacture, Ogden pub co. New York (1953).

[8] Society of Glass Technology, "Coloured glasses", Woldemar A.Weyl, 541 (1976).

[9] R. S.Boynyon, "Chemistry and Technology of Lime and Limestone, $2^{\text {nd }}$ Edition, Wiley (1980).

[10] N.J.Martin, Lighting Research and Technology 8, 3 (1976) 146.

[11]H.A.Strobel"Chemical Instrumentation", Addison-Wesly (1973).

[12] C.K.Hsieh, K.C.Su, Solar Energy 22, 1 (1979) 37.

[13] Greene C.H.,Grant J.A. "Glass Engineering Handbook", Lherary Licensing. LLC (2012).

[14] Bamford C.R."Colour Generation and Control in Glass", Elsevier Scientific Publishing Co., Amsterdam and New York 224 (1977).

[15] C.J. Kumar, M.A.Shadiya, E.K.Sunny, N.Raghu, N.Venkataramani, A.R Kulkarni, Journal of the American Ceramic Society 93, 10 (2010) 3027. 